Staropolska SzKo£a Wyższa, WydZiAE W DUblinie

\title{
SZKOLNICTWO POLONIJNE W WIELKIEJ BRYTANII I IRLANDII
}

SŁowa KLuCzowe: SZKolnictwo poloniJne W Wielkiej BrytaniI I IrlandiI, polskie SZKOLY UZUPELNIAJĄCE, POLSKIE SZKOŁY SOBOTNIE

\section{WSTĘP}

Niniejszy artykuł prezentuje historię, cele i perspektywy szkolnictwa polonijnego w Wielkiej Brytanii i Irlandii ${ }^{1}$. Choć osadnictwo polskie w Wielkiej Brytanii ma wiele dłuższą historię od zbiorowości polskiej w Irlandii, warto zestawić rozwój szkolnictwa polonijnego na obu wyspach. Wspólne okazują się bowiem nie tylko działania mające na celu zachowanie polskości wśród najmłodszego pokolenia Polaków za granicą, ale i problemy, jakim stawiają czoła polskie szkoły uzupełniające w obu krajach.

\section{Szkolnictwo poloniJne W Wielkiej BRYTANII Od 1830 ROKU}

Emigracja polska do Wielkiej Brytanii po powstaniu listopadowym charakteryzuje się rozpoczęciem aktywności na polu społecznym i kulturowym. Polacy zaczęli wówczas organizować swoje życie w Wielkiej Brytanii poprzez tworzenie różnego rodzaju ugrupowań, jak Towarzystwo Demokratyczne Polskie, Literackie Towarzystwo Przyjaciół Polski czy Towarzystwo Dam dla Popierania Uczącej się Młodzieży Polskiej [Paradowska 1992: 413-417]. Polska aktywność polityczna i społeczna skutkowała zainteresowaniem się działaniami na rzecz polskiej oświaty w Wielkiej Brytanii. Pierwsze szkółki powstają w latach trzydziestych i czterdziestych XIX wieku i są zakładane przez polskich robotników i działaczy politycznych

\footnotetext{
${ }^{1}$ Na potrzeby niniejszego artykułu termin Irlandia odnosi się do Republiki Irlandii.
} 
w Sheffield i Manchesterze [Korpukowiak 1992: 94]. Do czasów pierwszej wojny światowej inicjatywy na rzecz tamtejszego szkolnictwa polskiego nie były zjawiskiem systematycznym i powszechnym. Można przypuszczać, że głównym powodem była niewielka wciąż liczebność społeczności polskiej zamieszkującej wówczas Wielką Brytanię.

Po napływie kolejnych emigrantów polskich (po Wiośnie Ludów, powstaniu styczniowym i wydarzeniach Komuny Paryskiej) można zauważyć kolejne działania w stronę zachowania i propagowania polskości wśród emigracji w Wielkiej Brytanii. Od 1852 roku w Londynie działały dwie polskie szkółki wspierane przez starsze pokolenie Polaków na emigracji, którzy utworzyli Towarzystwo Naukowej Pomocy dla Dzieci Emigrantów [Paradowska 1992: 417]. W latach sześćdziesiątych organizacją polskiego szkolnictwa zajmowali polscy księża, w Londynie ks. Emeryk Podolski, a w Liverpoolu ks. Julian Dutkiewicz [Paradowska 1992: 417]. W 1886 swoją działalność w Wielkiej Brytanii rozpoczyna Towarzystwo Polskie w Londynie, które zajmuje się organizowaniem różnego rodzaju wsparcia dla emigrantów. Opiekę duszpasterską zapewniała wówczas Polakom Polska Misja Katolicka, która powstała w 1894 roku w Londynie [Historia Polskiej Misji Katolickiej w Anglii]. Dzięki dwóm siostrom, które przybyły z Matką Siedliską, współzałożycielką PMK, powstaje pierwsza polska szkółka pod opieką PMK. Od 1905 roku Polacy w Londynie objęci są opieką duszpasterską salezjanina, ks. Grzegorza Domańskiego. W 1905 roku w wydzierżawionym byłym domu marynarzy przy Mercer Street w Londynie powstaje polska kaplica z mieszkaniem dla rektora, a także szkółka sobotnia oraz biblioteka z czytelnią [Historia Polskiej Misji...]. Od 1903 roku przez kilka lat działa w Londynie Towarzystwo Wszechnicy Mickiewicza, które miało na celu wspieranie studiujących tam Polaków - organizacja upada z powodu problemów finansowych [Paradowska 1992: 417]. W 1931 w Londynie przy Towarzystwie Polskim powstała szkółka polska, która od 1935 roku znalazła się pod wspólną opieką Towarzystwa Polskiego i Polskiej Misji Katolickiej [Paradowska 1992: 419]. W latach 30. XX wieku Polacy skupiają się w dwóch ośrodkach - Londynie i Manchesterze. Działają tam między innymi w Londynie: Polskie Towarzystwo Katolickie, Koło Polaków studiujących w Londynie, Koło Polsko-Angielskie; natomiast w Manchesterze: Koło Polskie.

Druga wojna światowa w znaczący sposób odmieniła rzeczywistość polskiej zbiorowości w Wielkiej Brytanii. Zmiany zaszły zarówno w charakterze i liczebności emigracji polskiej (która nigdy wcześniej nie była tak liczna), jak i organizacji życia politycznego, społecznego oraz kulturalnego tamtejszych Polaków. W 1940 roku, po kapitulacji Francji i w następstwie spotkania gen. Władysława Sikorskiego z Winstonem Churchillem, do Wielkiej Brytanii został ewakuowany polski rząd, naczelne dowództwo i spora część polskiej armii, a Londyn stał się siedzibą władz Rzeczypospolitej Polskiej na Uchodźstwie (i pozostał przy tej funkcji do 1990 roku) [Serwański 1992: 424-425]. Rząd polski na emigracji poświęcał wiele uwagi kwestiom szkolnictwa polskiego w Wielkiej Brytanii oraz umożliwieniu polskim dzieciom i młodzieży podjęcia nauki w polskich szkołach na poziomie podstawowym, 
średnim i wyższym. Powyższe cele starał się realizować Urząd Oświaty (od 1941 roku: Urząd Oświaty i Spraw Szkolnych), na czele którego stanął gen. Józef Haller [Serwański 1992: 425-426]. Od 1943 roku zwierzchnictwo nad oświatą polską na emigracji sprawowało Ministerstwo Wyznań Religijnych i Oświecenia Publicznego, którego działania wspierały rozmaite instytucje, przy udziale których (a także dzięki przychylność i pomocy finansowej ze strony Zjednoczonego Królestwa) rozwinięto sieć polskich szkół o różnorodnym charakterze: powszechnych, średnich, ogólnokształcących, zawodowych, handlowych czy korespondencyjnych [Serwański 1992: 428-429]. Przy angielskich i szkockich uczelniach wyższych założono polskie jednostki akademickie. W 1943 roku uruchomiono Studium Pedagogiczne przy Uniwersytecie w Edynburgu - jego absolwenci przyczynili się do rozwoju szkół polonijnych w latach pięćdziesiątych, sześćdziesiątych i siedemdziesiątych [Serwański 1992: 428].

W 1945 roku, po konferencji w Teheranie i Jałcie, Wielka Trójka (Stalin, Roosevelt i Churchill) uznała podległy Moskwie Tymczasowy Rząd Jedności Narodowej za władze Polski, co skutkowało postępującym wycofaniem uznania dla polskich władz Rzeczypospolitej Polskiej na Uchodźstwie także przez inne kraje. Sytuacja ta wiązała się z brakiem dalszego wsparcia (również finansowego) ze strony brytyjskiej dla różnorodnej polskiej działalności i aktywności w Zjednoczonym Królestwie, co z kolei skutkowało zamykaniem polskich szkół i wydziałów szkół wyższych [Radzik 1992: 453]. Od 1945 do 1947 roku polska oświata w Wielkiej Brytanii znajdowała się pod nadzorem Tymczasowego Komitetu Skarbu dla Spraw Polskich - członkami Działu Oświaty ITC byli dawni pracownicy Ministerstwa Wyznań Religijnych i Oświecenia Publicznego, a kierownikiem profesor Tadeusz Sulimirski [Radzik 1992: 453]. W 1947 roku uchwalona przez brytyjski parlament ustawa o osiedleniu Polaków (Polish Resettlment Act) zobligowała brytyjskie Ministerstwo Oświaty do nadzorowania i pokrycia finansów polskiego szkolnictwa na Wyspie. W 1947 roku przy brytyjskim Ministerstwie Oświaty utworzono Komitet dla Spraw Oświaty Polaków w Wielkiej Brytanii (Committee for the Education of Poles in Great Britain), który działał do 1954 roku [Radzik 1992: 453]. Pod opieką komitetu otwierano polskie szkoły oraz polskie uczelnie wyższe, spośród których warto wspomnieć powstały w 1949 i działający do dziś Polski Uniwersytet na Obczyźnie [Radzik 1992: 455].

Do końca lat czterdziestych w Wielkiej Brytanii funkcjonowała większość polskich szkół zawodowych i ogólnokształcących, które powstały jeszcze w czasach drugiej wojny światowej. Sytuacja uległa jednak zmianie już na początku lat pięćdziesiątych, kiedy to Brytyjczycy zaczęli stopniowo wprowadzać do polskich szkół programy angielskie, a także likwidować jednostki kierowane do tej pory przez Komitet dla Spraw Oświaty Polaków w Wielkiej Brytanii [Radzik 1992: 456-458]. W odpowiedzi na zaistniałą sytuację na początku lat pięćdziesiątych swoją działalność reaktywuje Polska Macierz Szkolna - organizacja mająca swoje korzenie jeszcze w czasach zaborów, założona oficjalnie w kwietniu 1905 roku w Warszawie z inicjatywy inż. Józefa Świątkowskiego, a której pierwszym prezesem był Henryk 
Sienkiewicz [Historia Polskiej Macierzy Szkolnej]. Instytucja przerwała działalność w związku z wybuchem drugiej wojny światowej, a w 1953 roku reaktywowała się w Wielkiej Brytanii z inicjatywy m.in. generała Andersa (pierwszego przewodniczącego Rady PMS). Pod jej patronatem znalazły się nieobowiązkowe polskie szkoły nauczania przedmiotów ojczystych, które, począwszy od lat pięćdziesiątych, rozwijały działalność na większą skalę. Organizacja zajęła się także wydawaniem pomocy naukowych dla dzieci i nauczycieli oraz organizacją szkoleń i konferencji dla polskich pedagogów w Wielkiej Brytanii. Głównym celem PMS oraz polskich szkół przedmiotów ojczystych było szerzenie polskości wśród dzieci i młodzieży polskiej zamieszkującej Zjednoczone Królestwo i uczęszczającej do szkół anglojęzycznych [Historia Polskiej Macierzy Szkolnej]. Szkoły przedmiotów ojczystych otwierane były zazwyczaj spontanicznie przez rodziców i przy wsparciu polskich organizacji społecznych, jak wymienione wyżej Polska Macierz Szkolna, Stowarzyszenie Polskich Kombatantów i Zrzeszenie Nauczycieli Polskich. Placówki zazwyczaj finansowali sami rodzice, ale często uzyskiwały one pomoc od polskich organizacji i parafii w Wielkiej Brytanii. Zajęcia miały charakter nieobowiązkowy (dodatkowy w stosunku do obowiązku uczęszczania do szkół brytyjskich), a nauczano przede wszystkim języka polskiego, historii i geografii Polski, a także religii. Placówki mieściły się zwykle przy polskich parafiach, Domach Kombatanta czy Domach Polskich lub w wynajmowanych salach szkół brytyjskich [Radzik 1992: 459-461]. Lata sześćdziesiąte i siedemdziesiąte XX wieku były okresem największej aktywności i rozwoju polskich szkół przedmiotów ojczystych, do których uczęszczały kolejne pokolenia polskich emigrantów przybyłych tam w czasach drugiej wojny lub bezpośrednio po niej. W roku 1965 funkcjonuje 95 polskich szkół uzupełniających, w których uczy się łącznie 7000 Polaków; w roku 1970 liczba szkół wynosi 110, a uczniów 6992; w roku 1977 funkcjonuje 81 szkół, które kształcą 5053 uczniów [Radzik 1992: 460].

W latach osiemdziesiątych i dziewięćdziesiątych widać wyraźny spadek zainteresowania ofertą edukacyjną polskich szkół przedmiotów ojczystych. W 1981 w Wielkiej Brytanii działa 68 szkół polonijnych, w roku 1983 - 64 placówki, a w 1989 - 56 placówek z łączną liczbą uczniów wynoszącą około 2600 osób [Radzik 1992: 460]. Problemem był zazwyczaj fakt, że dla kolejnego pokolenia polskich emigrantów (wnukowie i prawnukowie Polaków przybyłych w latach czterdziestych) język angielski coraz częściej był już językiem pierwszym i dzieci miały z nim wielokrotnie częstszy kontakt niż z językiem polskim - chociażby ze względu na ustawowy obowiązek uczęszczania do anglojęzycznych szkół. Sytuację pogarszały niedostosowane podręczniki i program nauczania w szkołach przedmiotów ojczystych opracowany przez ZNPZ w latach pięćdziesiątych. W 1990 w Wielkiej Brytanii działało 65 szkół przedmiotów ojczystych - wiele z nich do końca lat dziewięćdziesiątych zamknięto [Radzik 1992: 460]. Sytuacja polskich szkół przedmiotów ojczystych w Zjednoczonym Królestwie do momentu wstąpienia Polski do Unii Europejskiej ulegała ciągłemu pogorszeniu, a ich liczba malała z roku na rok.

Należy podkreślić, że polska emigracja wojenna i powojenna stworzyła niezwykle rozwiniętą sieć organizacji oraz instytucji, dzięki którym Wielka Brytania stała 
się tak ważnym ośrodkiem polskiej nauki i kultury poza granicami kraju. Wśród najważniejszych inicjatyw należy wymienić Bibliotekę Polską, Polski Ośrodek Naukowy, a także Instytut Historyczny im. gen. Sikorskiego w Londynie, Polskie Zjednoczenie w Wielkiej Brytanii, Towarzystwo Naukowe na Obczyźnie z siedzibą w Londynie [Radzik 1992: 449].

Wstąpienie Polski w ramy Unii Europejskiej zapoczątkowało kolejną falę emigracji do Wielkiej Brytanii, co wiąże się także z ponownym rozkwitem życia społecznego tamtejszej zbiorowości polskiej. Działalność kontynuują lub wznowiły organizacje powstałe tam już przed laty, pojawiły się także nowe inicjatywy. Powstały polskie organizacje społeczno-kulturowe wspierające podtrzymanie polskiej tożsamości narodowej, powiększył się rynek prasowy i wydawniczy (nieprzerwanie od 1940 roku ukazuje się „Dziennik Polski”), powstają polskie sklepy, zakłady usług fryzjerskich i kosmetycznych, polskie przychodnie. Po 2004 roku wzrosło również zainteresowanie szkolnictwem polonijnym - gwałtownie powiększyła się liczba uczniów w działających już placówkach. Wzrosła także ilość szkół polonijnych w Wielkiej Brytanii - obecnie działa około 160 placówek (z których ponad 130 jest zrzeszonych w Polskiej Macierzy Szkolnej w Wielkiej Brytanii) oraz dwa Szkolne Punkty Konsultacyjne ${ }^{2}$. Młodzież polonijna ma możliwość zdawania języka polskiego na egzaminach GCSE (General Certificate of Secoundary Education - odpowiednik polskiego egzaminu gimnazjalnego) oraz GCSE A-level (General Certificate of Education Advanced Level - odpowiednik polskiego egzaminu maturalnego), a wiele polskich szkół uzupełniających oferuje kursy przygotowawcze do tych egzaminów.

\section{SZKolNiCTWO POLONIJNE W IRLANDII}

Choć liczba Polaków w Irlandii przed wstąpieniem Polski do Unii Europejskiej była niewielka, wynosiła około 2000 osób [Rakowski 2012: 178], już w 1979 roku powstało w Dublinie Towarzystwo Irlandzko-Polskie, a w latach osiemdziesiątych Polski Ośrodek Społeczno-Kulturalny [Płachecki 2012: 125]. Organizacje po dziś dzień prowadzą działalność ukierunkowaną na wspieranie integracji oraz przyjaźni między społecznością polską i irlandzką.

Po wstąpieniu Polski do Unii Europejskiej nastąpił gwałtowny napływ ludności polskiej do Irlandii, a co za tym idzie - rozwój polskiego życia społecznego. Powstały liczne polskie stowarzyszenia i organizacje o rozmaitym charakterze, między innymi: Centrum Integracji i Wsparcia „Together - Razem”, Polski Klub Biznesu, Stowarzyszenie My Cork, Forum Polonia, Stowarzyszenie Edukacyjne Nauczycieli SEN, Zespół Pieśni i Tańca „Koniczyna” [Płachecki 2012: 129-136]. Wzrost liczebności społeczności polskiej w Irlandii skutkował także powstaniem polskich szkół uzupełniających oraz Szkolnych Punktów Konsultacyjnych przy Ambasadzie RP. Obecnie w Republice Irlandii działa 36 polskich szkół społecznych (w tym 20 zrzeszonych w PMSI) oraz pięć Szkolnych Punktów Konsultacyjnych przy Ambasadzie

\footnotetext{
${ }^{2}$ Informacje podane przez Ambasadę RP w Londynie i Polską Macierz Szkolną w Wielkiej Brytanii.
} 
RP zlokalizowanych w: Dublinie, Waterford, Limerick, Cork i Cavan ${ }^{3}$. W Irlandii funkcjonuje także wiele polskich przedszkoli, a polskie szkoły uzupełniające prowadzą kursy przygotowujące uczniów do irlandzkiego egzaminu Leaving Certificate (odpowiednik polskiego egzaminu maturalnego) z języka polskiego.

W 2012 roku działalność rozpoczęła Polska Macierz Szkolna w Irlandii (PMSI) - organizacja angażuje się w życie Polonii w Republice Irlandii, zrzesza i wspiera tamtejsze szkoły polonijne, a także organizuje różnego rodzaju konferencje i sympozja dla nauczycieli oraz konkursy dla dzieci [Polska Macierz Szkolna w Irlandii]. Wśród organizowanych przy współpracy PMSI form doskonalenia dla nauczycieli i aktywizacji uczniów polskich szkół warto wymienić: coroczne Konferencje Metodyczne organizowane przez PMSI oraz Ośrodek Doskonalenia Nauczycieli Stowarzyszenia „Wspólnota Polska” od 2014 roku, IV Europejskie Sympozjum Polskich Macierzy Szkolnych, którego tematem było „Szkolnictwo polonijne w dobie przemian Europy - diagnoza, rola i perspektywy" (listopad 2014 roku, Dublin), szkolenie metodyczne: „Planuj i oceniaj kształtująco” zorganizowane przez Fundację Edukacja dla Demokracji i Polską Macierz Szkolną w Irlandii (październik-listopad 2015). Spośród licznych działań ukierunkowanych w stronę najmłodszego polskiego pokolenia w Irlandii trzeba wspomnieć akcję promującą i zachęcającą do zdawania irlandzkiej matury z języka polskiego („Leaving Cert Polish”) oraz liczne konkursy dla uczniów polskich szkół uzupełniających: ortograficzny „Mistrz Ortografii” (4 edycje), recytatorski „Lokomotywa” (2 edycje), filmowy „Telebłyski 2016" i plastyczny (12 edycji). Dzięki działaniom PMSI polskie szkoły sobotnie wprowadzone zostały jednolite świadectwa szkolne dla szkół polonijnych w Irlandii. Polska Macierz Szkolna w Irlandii współpracuje ze Staropolską Szkołą Wyższą, której dubliński wydział oferuje zdobycie kwalifikacji nauczycielskich poprzez studia na kierunkach: pedagogika wczesnoszkolna, podyplomowe studia pedagogiczne, oligofrenopedagogika. Od wielu lat PMSI działa na rzecz wprowadzenia języka polskiego do irlandzkich szkół średnich, a także promuje równy dostęp do edukacji polonijnej dla wszystkich dzieci polskiego pochodzenia.

W Irlandii odbyły się już trzy edycje Festiwalu Polska-Eire (w latach: 2015, 2016 i 2017), organizowanego pod auspicjami Polskiej Ambasady w Dublinie, mającego na celu promowanie integracji, szerzenie wiedzy o Polsce wśród Irlandczyków, a także zapoznawanie Polaków z kulturą Irlandii [Polska Éire Festival]. W tym celu w ramach festiwalu w całej Irlandii odbywają się liczne występy artystyczne, wystawy fotograficzne, konferencje i dyskusje naukowe oraz wydarzenia sportowe.

\section{ZASADY FUNKCJONOWANIA SZKÓŁ POLONIJNYCH - PODSTAWY PRAWNE} I REALIZOWANE CELE

Szkoły polonijne w Wielkiej Brytanii i Irlandii mają charakter uzupełniający w stosunku brytyjskiego i irlandzkiego systemu szkolnictwa (nie należą do brytyjskiego ani irlandzkiego systemu edukacyjnego). Dzieci polskie wychowujące się na

\footnotetext{
${ }^{3}$ Informacje podane przez Ambasadę RP w Dublinie oraz Polską Macierz Szkolną w Irlandii.
} 
Wyspach Brytyjskich podlegają obowiązkowi szkolnemu wynikającemu z tamtejszego prawa; uczęszczają więc do szkół brytyjskich i irlandzkich w tygodniu, natomiast $\mathrm{w}$ weekendy mają możliwość poszerzenia wiedzy z zakresu języka polskiego i wiedzy o Polsce w placówkach polonijnych.

Polonijne szkoły uzupełniające różnią się pod względem podstaw prawnych, wedle których funkcjonują. Polonijne szkoły uzupełniające różnią się pod względem podstaw prawnych, wedle których funkcjonują. Funkcjonowanie i podstawy prawne szkolnictwa polskiego za granicą określone zostały w Rozporządzeniu Ministra Edukacji Narodowej i Sportu z dnia 2 września 2004 r. (Dz.U. z 2004 r. $\mathrm{Nr}$ 194, poz.1986), a następnie w Rozporządzeniu Ministra Edukacji Narodowej z dnia 31.08.2010 roku (Dz.U. Nr 10, poz.1443) w sprawie organizacji kształcenia dzieci obywateli polskich czasowo przebywających za granicą. Wyróżnia się dwa rodzaje uzupełniających szkół przedmiotów ojczystych:

1. Szkolne Punkty Konsultacyjne (przy przedstawicielstwach dyplomatycznych, urzędach konsularnych i przedstawicielstwach wojskowych Rzeczypospolitej Polskiej) - działalność Szkolnych Punktów Konsultacyjnych jest w całości finansowana przez Ministerstwo Edukacji Narodowej i nadzorowana przez Ośrodek Rozwoju Polskiej Edukacji za Granicą. Trzeba podkreślić, że SPK działają na zasadzie eksterytorialności, dlatego też ich organizacja, struktura, powoływanie dyrekcji, programy zajęć oraz dobór podręczników są koordynowane i podlegają MEN oraz ORPEG. Początkowo placówki te kształcić miały jedynie dzieci polskich przedstawicieli dyplomatycznych i wojskowych, jednak po 1991 roku zaczęto przyjmować dzieci polskich emigrantów przebywających za granicą. Zajęcia w SPK odbywają się w weekendy (sobota, niedziela).

2. Szkoły społeczne lub prywatne - zazwyczaj organizacje non-profit, utrzymują się i powadzą działalność dzięki składkom wpłacanym przez rodziców uczniów, a także dzięki wsparciu z ramienia polskich ambasad i innych organizacji. Szkoły społeczne samodzielnie organizują swoje struktury i plany zajęć. Zajęcia odbywają się w soboty w godzinach przedpołudniowych lub w wybrane dni tygodnia (popołudniami i wieczorami); często w salach wynajmowanych na ten czas w lokalnych szkołach. Programy zajęć obejmują przede wszystkim naukę języka polskiego, wiedzy o Polsce (historii i geografii), religii. W wielu szkołach dostępne jest nauczanie dwustopniowe, tj. szkoła podstawowa i liceum, a niejednokrotnie prowadzone są także zajęcia przedszkolne i klasy zerowe. Część placówek prowadzi też specjalne kursy przygotowujące uczniów do matury z języka polskiego za granicą, a nawet kursy języka angielskiego dla rodziców.

Cele, jakie stawiają sobie polskie placówki szkolne, to przede wszystkim zachęcanie do poznawania i używania polszczyzny, wzbudzanie zainteresowania Polską, jej kulturą i tradycjami, a tym samym budowanie poczucia tożsamości i więzi z Polską. W tym celu wiele szkół polonijnych układa i realizuje program edukacyjny w oparciu o podstawę programową wydaną przez MEN w 2010 roku [Podstawa programowa dla uczniów polskich uczacych się za granica]. Równie istotną kwestią oświaty polonijnej jest pielęgnowanie dwujęzyczności i dwukulturowości młodych 
Polaków oraz motywowanie do dalszego życia w szacunku dla obu języków i kultur. Działalność polskich szkół uzupełniających nastawiona jest także na integrację polskich środowisk lokalnych przez organizowanie różnego rodzaju wydarzeń, jak kiermasze książek, zawody sportowe, wspólne kolędowanie.

\section{ProblemY I PERSPEKTYWY POLSKICH SZKóŁ UZUPEeNIAJĄCYCH ${ }^{4}$}

Do najpoważniejszych problemów, z jakimi borykają się tamtejsze społeczne i prywatne szkoły polonijne, należą kwestie natury finansowej. Nauczyciele podkreślają też, że brakuje dobrze opracowanych podręczników do nauki języka polskiego w szkołach weekendowych. Kolejną problematyczną kwestią są relacje z rodzicami - na pierwszy plan wysuwa się tu często słabe zaangażowanie w rozwój znajomości języka polskiego u swoich dzieci. Nauczyciele podkreślają również różnice w poziomie znajomości języka polskiego wśród dzieci polonijnych w jednym wieku, a także wpływ języka angielskiego na ich polszczyznę. Podkreślane są między innymi problemy związane z ubogim słownictwem i słabą znajomością gramatyki języka polskiego - są to jednak naturalne konsekwencje dwujęzyczności, dzieci przyswajają bowiem dwa systemy językowe, dlatego może im to zająć więcej czasu, a w konkretnych dziedzinach może przeważać znajomość słownictwa tylko jednego z języków. Kolejnym problemem jest nierówny dostęp do szkół i nauki języka polskiego za granicą, który poruszono podczas zgromadzeń Rady Oświaty Polonijnej PMS w Irlandii. Dzieci uczęszczające do SPK pobierają naukę za darmo, podczas gdy rodzice dzieci uczących się w szkołach społecznych muszą płacić za zajęcia swoich pociech.

Przyszłość polskiego szkolnictwa uzupełniającego jest bezpośrednio związana z liczebnością polskiej emigracji i stopniami akulturacji/adaptacji Polaków w krajach zamieszkania. W badaniach strategii akulturacyjnych porównuje się stosunek Polaków za granicą do kultury polskiej i kultury kraju pobytu. Na tej podstawie wyróżnia się cztery strategie akulturacyjne: separacja, marginalizacja, integracja, asymilacja [Cierpiałkowska, Żabińska 2010: 327-329]. Wyniki badań nad stopniami akulturacji Polaków w Wielkiej Brytanii i Irlandii pokazują, że tamtejsza społeczność polska ma pozytywny stosunek zarówno do kultury rodzimej, jak i kultury kraju osiedlenia - chętnie bierze udział w życiu lokalnej społeczności, a jednocześnie nie rezygnuje z polskiej tożsamości i uważa docenia rolę dwujęzyczności młodszego pokolenia [Dabaene 2010: 94-99; Ereciński, Stefanicka, Scholl-Mazurek 2014].

Zainteresowanie nauką $\mathrm{w}$ polskich szkołach uzupełniających uzależnione jest również od przynależności do danego pokolenia polonijnego. Wyróżnia się pokolenie emigracyjne - osoby urodzone z Polsce, które wyemigrowały z Polski, pierwsze pokolenie polonijne - dzieci emigrantów (zarówno urodzone w Polsce, jak i w kraju

${ }^{4}$ Przytoczone w artykule problemy szkół polonijnych zostały wymienione przez nauczycieli polonijnych w ankietach przeprowadzonych przez autorkę artykułu w 2015 roku w ramach badań do pracy magisterskiej pt. Język dzieci polonijnych w Wielkiej Brytanii i Irlandii po 2004 r. - w kontekście uwarunkowań historycznych, napisanej pod opieką prof. UKSW, dr hab. Anny Szczepan-Wojnarskiej i obronionej w lipcu 2015 roku na Uniwersytecie Kardynała Stefana Wyszyńskiego w Warszawie. 
przyjmującym); drugie pokolenie polonijne - wnuki emigrantów, i tak dalej [Dubisz 1983: 292-301]. Pokolenie emigracyjne stanowi łącznik z ojczyzną, ponieważ tam się wychowali i stamtąd znają polszczyznę, kulturę i tradycje polskie [Dubisz 1983: 295]. Przedstawiciele drugiej generacji zazwyczaj (choć nie jest to regułą) tworzą pokolenie dwujęzyczne i dwukulturowe, które w warunkach naturalnych przyswaja oba systemy językowe (na przykład: w szkole - język angielski, w domu - język polski). Wnuki polskich emigrantów wychowywane za granicą przeważnie znają język kraju zamieszkania w lepszym stopniu niż język polski. Zainteresowanie udziałem w zajęciach polskich szkół uzupełniających zazwyczaj maleje wśród przedstawicieli kolejnych pokoleń. Trzeba jednak pamiętać, że na stosunek do polskiego pochodzenia $\mathrm{i}$ chęć pielęgnowania więzi z Polską wpływają rozmaite czynniki, jak wychowanie, częstotliwość kontaktu z rodziną z Polski, częstotliwość przyjazdów do Polski. Zatem zarówno dwujęzyczność młodych Polaków za granicą, jak i ich zainteresowanie Polską może przybierać różny poziom nawet w obrębie przedstawicieli jednej generacji polonijnej.

\section{Bibliografia}

CierPialKowsKa L., ŻABIŃSKa S. [2010], Uwarunkowania poziomu adaptacji polskich emigrantów w Edynburgu, [w:] Drogi i rozdroża. Migracje Polaków w Unii Europejskiej po 1 maja 2004 roku. Analiza psychologiczno-socjologiczna, Grzymała-Moszczyńska H., Kwiatkowska A., Roszak J. (red.), NOMOS, Kraków.

Dabaene E. [2010], Dialog międzykulturowy. Polska diaspora a spoteczeństwo irlandzkie po roku 2004, [w:] Drogi i rozdroża. Migracje Polaków w Unii Europejskiej po 1 maja 2004 roku. Analiza psychologiczno-socjologiczna, Grzymała-Moszczyńska H., Kwiatkowska A., Roszak J. (red.), NOMOS, Kraków.

DuBISZ S. [1983], Z metodologii badań języka środowisk polonijnych, „Poradnik Językowy", z. 5.

Ereciński Ł., Stefanicka K., Scholl-Mazurek K. [2014], Polska Spoleczność w Wielkiej Brytanii. Integracja, Partycypacja Społeczna oraz Samopoczucie Polaków w Ujęciu Psychologicznym, http://www.polishpsychologists.org/wp-content/uploads/2012/12/PPA_Raporrt_PL_v1.pdf [dostęp: 09.10.2016].

Historia Polskiej Macierzy Szkolnej, http://www.polskamacierz.org/o-nas/historia-naszej-organizacji [dostęp: 09.10.2016].

Historia Polskiej Misji Katolickiej w Anglii, http://www.pcmew.org/pages/o-nas/ historia [dostęp: 09.10.2016].

Korpukowniak A. [1992], Oświata i szkolnictwo polonijne, [w:] Polonia w Europie, Szydłowska-Ceglowa B. (red.), PAN, Poznań.

Paradowska K. [1992], Polacy w Wielkiej Brytanii do 1939 roku, [w:] Polonia $w$ Europie, Szydłowska-Ceglowa B. (red.), PAN, Poznań.

PŁachecki, J. [2012], Organizacje polonijne powstate po 2004 r., [w:] Polska emigracja w Irlandii w XX i na początku XXI wieku, J. Płachecki (red.), Żyrardów-Dublin. 
Podstawa programowa dla uczniów polskich uczacych się za granica, http://www. polska-szkola.pl/file.php/1/Podstawa_programowa_INTERNET.pdf [dostęp: 27.07.2017].

Polska Éire Festival, http://polskaeirefestival.org/festival/ [dostęp: 27.07.2017].

Polska Macierz Szkolna w Irlandii, http://www.polskamacierz.com [dostęp: 27.07.2017].

RADZIK T. [1992], Społeczność polska w Wielkiej Brytanii w latach 1945-1990, [w:] Polonia w Europie, Szydłowska-Ceglowa B. (red.), PAN, Poznań.

Rakowski W. [2012], Przeptyw ludności między Polska a Irlandia, [w:] Polska emigracja w Irlandii w XX i na początku XXI wieku, J. Płachecki (red.), Żyrardów-Dublin.

SerwaŃski J. [1992], Polacy w Wielkiej Brytanii w latach II wojny światowej, [w:] Polonia w Europie, Szydłowska-Ceglowa B. (red.), PAN, Poznań. 